\title{
O desprezo da política eleitoral: crise da representação e legitimidade contra-democrática na obra de Pierre Rosanvallon
}

\author{
The despise of electoral politics: crisis of representation and counter- \\ democratic legitimacy on Rosanvallon's work
}

\section{Luanda Dias Schramm}

\section{Resumo}

$\mathrm{O}$ artigo analisa as transformaçóes recentes na democracia representativa a partir das contribuiçóes de Pierre Rosanvallon, sob a perspectiva de uma democracia mais justa e equitativa. Rosanvallon se opóe à redução da política democrática ao procedimento eleitoral, e propóe uma teorização que pretende ampliar o sentido da açáo política para além do mecanismo eleitoral. A ideia de contra-democracia integra o conjunto das instituiçóes que agiriam como contraponto, criando novas formas de legitimação política, ausentes nas concepçóes minimalistas de democracia eleitoral. Em vez de lamentar a queda do sistema eleitoral como véiculo da vontade popular, o autor francês celebra a emergência de formas não eleitorais de accountability. $\mathrm{O}$ artigo argumenta que, embora pretenda ampliar o sentido da ação política para além da representação formal, o autor promove a desqualificação da política eleitoral e despolitiza a representação em benefício de poderes não eleitos.

\section{Palavras-chave}

Representação; Participação; Legitimação; Democracia.

\begin{abstract}
The paper analyzes the recent transformations in representative democracy in the contributions of Pierre Rosanvallon, from the perspective of a more just and equitable democracy. Rosanvallon opposes the reduction of democratic politics to the electoral procedure, and proposes a theory that intends to expand the meaning of political action beyond electoral mechanism. The idea of counter-democracy integrates all the instiutuitions that would act as counterpoint, creating new forms of political legitimation, absent in the minimalist conceptions of electoral democracy. Instead of lamenting the fall of the electoral system as a vehicle of popular will, the French author celebrates the emergence of nonelectoral forms of accountability. The article argues that, although he intends to expand the meaning of political action beyond the formal representation, Rosanvallon promotes the disqualification of electoral politics and depoliticises the representation for the benefit of unelected powers.
\end{abstract}

\section{Keywords}

Representation; Participation; Legitimacy; Democracy. 


\section{Introdução ${ }^{1}$}

O objetivo do artigo é analisar as transformaçóes recentes na democracia e a alegada crise de representação a partir da obra de Pierre Rosanvallon, além de avaliar a pertinência dos argumentos do autor francês, sob a perspectiva da construção de uma democracia mais justa e equitativa.

Pierre Rosanvallon analisa o hiato entre a legitimação procedimental, conferida por eleiçóes, e a confiança política substantiva, crescentemente retirada dos governantes eleitos. Diante das evidências de que a democracia representativa não logrou realizar suas promessas, nem quanto aos direitos materiais nem quanto à participação efetiva dos cidadãos nas escolhas políticas, Rosanvallon faz uma reinterpretação das mudanças que sobrevieram, na contramão do questionamento dos efeitos antidemocráticos do ideário liberal. Ele argumenta que consiste numa incompreensão da democracia existente supor que ela falha em realizar os valores da soberania popular, aos quais ela preencheria de maneiras mais sutis e ricas do que usualmente imaginado, sobretudo pelo crescimento da sociedade civil autoorganizada, expandindo uma democracia indireta em torno e além dos sistemas eleitorais.

Ele propóe uma teorização que pretende ampliar o sentido da ação política para além do mecanismo eleitoral, pela observaçáo de poderes indiretos disseminados no corpo social, que ele define como a 'democracia da desconfiança generalizada', face à 'democracia da legitimidade eleitoral'. Para Rosanvallon, as eleiçóes conferem legitimidade a uma designação de mandato, mas a afirmação da soberania por meio de eleiçóes é insuficiente para conferir legitimidade aos atos e decisóes do mandatário.

As instituiçóes contra-democráticas que engendram novas formas de legitimação política são, na visão do autor, instrumentos de vigilância e avaliação dos governos, que concorrem ao exercício da cidadania e exercem um contrapoder para limitar o "absolutismo" dos governantes legitimados pelas eleiçóes. Tais "medidores

1 Versôes preliminares deste artigo foram discutidas no II Encontro Internacional Participação, Democracia e Políticas públicas, de 27 a 30 de abril de 2015, UNICAMP, Campinas-SP; no VI Seminário Nacional de Sociologia e Política, de 20 a 22 de maio de 2015, UFPR, Curitiba-PR; no I Seminário Internacional de Ciência Política, 9, 10 e 11 de setembro de 2015, UFRGS, Porto AlegreRS e no 39o Encontro Anual da ANPOCS, de 26 a 30 de outubro de 2015, Caxambu-MG. Agradeço aos comentários, críticas e sugestóes dos debatedores e participantes dos grupos de trabalho e também agradeço aos pareceristas anônimos da Revista Debates, o que não me exime das possíveis falhas que aqui insistiram em permanecer. 
de saúde democrática", porém, também podem promover o enfraquecimento da democracia, e aumentar a distância que separa governantes de governados. $\mathrm{O}$ artigo argumenta que a formulação do autor francês, embora parta de uma ampliação do sentido da ação política para além da representação formal, resulta numa redução da política, e também da democracia, no esteio das perspectivas elitistas e procedimentalistas.

\section{Democracia, eleições e representação}

Da cidadania democrática, como hoje a entendemos, faz parte, em qualquer caso, o sufrágio universal, cujo advento foi, por muito tempo, impossibilitado pelas cláusulas de exclusão estabelecidas pela tradiçáo liberal em detrimento dos povos coloniais e de origem colonial, das mulheres e dos não proprietários. E estas cláusulas, por sua vez, foram, por muito tempo, justificadas, assimilando os excluídos a "bestas de carga", a "instrumentos de trabalho", a "máquinas bípedes" ou, na melhor das hipóteses, a "crianças" (LOSURDO, 2004). O mito do ocidente democrático, hoje hegemônico, também quer fazer crer que democracia e livre mercado capitalista se identificam.

A democracia representativa, uma das variantes do governo representativo, surgiu no interior de uma tradição fortemente antidemocrática (MIGUEL, 2002) ${ }^{2}$. A democracia representativa só se tornou possível quando os teóricos do liberalismo perceberam que o voto universal náo ofereceria riscos ao direito de propriedade e nem a perpetuação das distinções de classe (MACPHERSON, 1977). Assim, a cidadania moderna se constitui a partir de uma compreensão que foi e tem sido projetada para ajustar um esquema de governo democrático a uma sociedade dividida em classes.

A ampliação das franquias eleitorais no governo representativo é geralmente vista como a realização da democracia, mas a incorporação das classes subalternas foi implementada para evitar a realização da democracia, diante do temor da presença popular, temor generalizado do risco de redistribuição da riqueza. $\mathrm{O}$ voto universal foi aceito com a condição de se apresentar como única forma de ação política

\footnotetext{
${ }^{2}$ Em "A democracia domesticada", Miguel discute as bases antidemocráticas da teoria da democracia, que se tornou dominante na chamada 'teoria das elites', que negava a possibilidade da democracia, e cujo diagnóstico foi adotado na construção da democracia liberal. Partindo da caracterização weberiana das democracias de massa, foi acrescida das contribuiçóes das vertentes economicista e pluralista do pensamento liberal, e tornou-se a teoria democrática dominante no pós-guerra.
} 
aceitável, o que deslegitima manifestaçóes coletivas e outras formas mais contundentes de ação, como greves e barricadas.

O caráter problemático do voto como meio de realizaçáo da democracia, segundo Albert Hirschman, não é o fato do resultado das eleiçôes ser preparado em vista da forma do poder econômico e político na sociedade, "mas o fato de tirar a legitimidade de outras formas mais diretas, intensas e 'expressivas' de ação política que, além de mais eficientes, são mais satisfatórias" (HIRSCHMAN, 1983, p. 125126). Na visão de Hirschman, o sufrágio é, antes, um meio de conservação do que de mudança, que privilegia uma forma de ação e não outras, e viabiliza a formação e expressão de um determinado tipo de interesse. "O sufrágio universal impede que os cidadãos manifestem a intensidade de seus sentimentos em relação a questôes públicas" (HIRSCHMAN, 1983, p. 113). O voto é a expressão de uma versão individualista do mundo social, favorece a expressão de interesses individualistas e desfavorece a expressão de interesses coletivos.

O governo representativo se instituiu como uma alternativa conscientemente escolhida ao autogoverno popular (MANIN, 1997). Uma característica desigual discutida e deliberadamente introduzida do governo representativo é a exigência de que os representantes sejam socialmente superiores àqueles que os elegeram. $\mathrm{O}$ governo representativo foi instituído com a plena consciência de que os representantes eleitos seriam e deveriam ser cidadáos distintos, socialmente diferentes daqueles que os elegeram ${ }^{3}$.

O mecanismo eleitoral consiste, a partir desse ponto de vista, em um modelo conservador, despolitizador, assombrado pela desconfiança permanente da participação popular; entretanto, possui elementos contraditórios, pois o voto introduz incerteza no processo político. Além do mais, a legitimidade da política eleitoral requer o atendimento de algumas demandas. O direito de voto propiciou a permeabilidade do sistema político aos não detentores de poder, mas, ao mesmo tempo, a conquista do direito de voto significou o estabelecimento de uma barreira à participação, pois o voto passou a ser a única forma legítima de intervir nas questóes

\footnotetext{
${ }^{3}$ Segundo Manin, a ideia comum de que a natureza náo democrática do governo representativo reside na restrição das franquias eleitorais, que foram gradualmente ampliadas ao longo dos séculos 19 e 20, ofusca a percepção de que, independente dessas restriçóes, havia também uma série de arranjos e circunstâncias que assegurariam que os eleitos seriam de um nível social mais elevado do que o eleitorado, objetivo comum alcançado de maneiras diferentes na Inglaterra, França e Estados Unidos (MANIN, 1997, p. 94).
} 
políticas, o que levou ao enfraquecimento das possibilidades de mobilização e ao arrefecimento da disputa política.

Uma característica comum entre os representantes da corrente dominante da teoria democrática é a concepção da democracia como um método político de competição entre líderes. Para Schumpeter (1987), o pai fundador dessa corrente, a democracia é uma teoria dissociada de ideais ou fins, é apenas um tipo de arranjo institucional para se chegar a decisóes políticas, que consiste na competiçấo dos líderes, aqueles que potencialmente tomam as decisóes, pelos votos do povo.

A democracia é assim destituída de todo elemento de participação popular. A participação política é papel exclusivo das lideranças. Ao cidadão comum, o único meio de participaçáo é o voto no líder, visto como forma de controle contra governos tirânicos. Embora afirme que o método democrático permite, em princípio, que qualquer pessoa possa competir em eleições livres, "Schumpeter pensava que, na verdade, era necessária uma classe política ou dominante para fornecer candidatos à liderança" (PATEMAN, 1992, p. 13). A teoria democrática de Schumpeter (1987) pressupóe que os cidadãos comuns são desinformados, apáticos e desinteressados. $\mathrm{O}$ 'analfabetismo político' caracteriza mesmo os eleitores mais instruídos. A incompetência política dos cidadãos comuns, entretanto, não consiste em um obstáculo ao funcionamento da democracia, visto que os cidadáos só decidem quem tomará decisōes sobre políticas concretas em seu lugar.

Assim, a concepçáo de cidadania que se depreende da teoria dominante da democracia está fundada em diferentes competências técnicas exigidas para a participação ativa no campo político e no monopólio profissional da produção das formas de expressão e de percepção politicamente atuantes e legítimas. Há uma defesa da separação entre os politicamente atuantes e os politicamente passivos. Tal concepção procedimental de democracia não se preocupa com o conteúdo das decisôes políticas, nem com os meios para implementá-las; reconhece, porém, a importância das liberdades civis como condiçôes necessárias ao funcionamento do método democrático.

Esse modelo de democracia, melhor definido por C.B. Macpherson (1977, p. 89) como um "modelo oligopolístico", apenas os membros das elites políticas, nos partidos e cargos públicos, é que têm participação efetiva. O papel político dos cidadãos é severamente limitado e até mesmo retratado como uma infração indesejada no funcionamento normal da tomada de decisão pública (HELD, 1996). Segundo Macpherson, o caráter democrático do elitismo competitivo reside táo 
somente na ideia de 'proteção contra a tirania' (MACPHERSON, 1977, p. 90-9), em que a periodicidade eleitoral consiste em um obstáculo aos excessos da liderança política.

O formalismo de uma definição baseada exclusivamente no correto funcionamento das regras do jogo termina por considerar irrelevantes não só direitos políticos (para não falar dos materiais), mas também os direitos civis dos cidadãos. Ao considerar a miséria de amplas massas como uma questão meramente privada, é possível considerar os direitos do homem como meramente formais (LOSURDO, 2004). Assim, a renúncia à categoria de democracia substancial é análoga à liquidação dos direitos sociais e econômicos (LOSURDO, 2004).

Nos países de tradição liberal consolidada, afirmou-se um tipo de mecanismo eleitoral que, além de reduzir a competição à disputa entre dois líderes mais ou menos carismáticos e de marginalizar os partidos organizados com base num programa - em primeiro lugar, os partidos ligados às classes subalternas, não hesita em cancelar o próprio princípio da soberania popular (LOSURDO, 2004).

Nas perspectivas liberais antidemocráticas mais extremadas, como a representada por Hayek $(1983)^{4}$, por exemplo, freqüentemente se recusa a reconhecer a universalidade do sufrágio como um direito subjetivo, como se não fosse nada mais do que função regulamentada pela sociedade, uma concessão a ser efetivada segundo as circunstâncias. (LOSURDO, 2004)

Apesar de estarmos diante de um quadro variado e contraditório, a tendência principal, no âmbito de um processo ainda em curso, é a de redução teórica da democracia. Uma vez que esta não consegue realizar suas promessas, nem quanto aos direitos materiais nem quanto à participação dos cidadãos nas escolhas políticas, procede-se a uma redefinição mínima que a adapta ao sistema político existente.

As diferentes reinterpretaçóes da democracia e do regime representativo como mercado político e como mecanismo procedimental para a produção de líderes não só expurgam os direitos sociais e econômicos do catálogo dos direitos, como compatibilizam democracia com exclusão da esfera da cidadania política de determinadas camadas sociais e étnicas. Conforme Losurdo (2004, p. 300), os teóricos do regime político que hoje triunfou procederam a uma redefinição e a uma

\footnotetext{
4 "Independentemente do peso dos argumentos a favor da democracia, ela não é um valor último, ou absoluto, e deve ser julgada pelo que realizar. Ela constitui provavelmente o melhor método para a consecução de certos fins, mas não é um fim em si mesma” (HAYEK, 1983, p. 115).
} 
redução drástica da democracia "da qual foi expurgada qualquer ideia de emancipação e até somente de participaçáo dos cidadãos e nas escolhas políticas". A democracia assim redefinida se presta magnificamente à relegitimação em chave democrática dos regimes mais oligárquicos.

Nadia Urbinati faz uma retificação a essa definiçáo minimalista de democracia, afirmando duas virtudes da competição eleitoral: ao passo que ela ensina os cidadáos a se livrarem dos governos pacificamente, ela também os faz participar do jogo de tornar a si mesmos livres dos governos. Dessa maneira, o direito ao voto, segundo ela, engendra uma vida política rica, promove agendas políticas concorrentes, condiciona a vontade dos legisladores de uma forma constante, náo apenas no dia da eleição. Encoraja o desenvolvimento amplo de formas extraeleitorais de ação política, realça o paradoxo da visão instrumentalista de representação, "a qual, por um lado, refere-se à opinião do povo como fonte de legitimidade e, por outro, sustenta que os representantes tomam decisóes boas e racionais conforme se protegem de uma 'opinião popular sempre manipulável'” (URBINATI, 2006, p. 204).

\section{Igualdade politica e individualismo liberal}

Pierre Rosanvallon adota uma visão patológica de democracia. Sua primeira trilogia da história da democracia na França deixa clara sua devoção à democracia liberal como o telos da política moderna, enquanto também ilumina as patologias das quais tanto o liberalismo quanto a democracia são, em sua visão, dotados. A convicçáo de Rosanvallon, inspirada na obra de Loius Dumont, de que o advento do indivíduo é a característica singular mais distintiva da modernidade, leva o autor a narrar a experiência francesa de individualismo e igualdade política no primeiro volume de sua primeira trilogia, Le sacre de citoyen (1992).

Rosanvallon traça a história da 'sagração do cidadáo'. Nessa obra, ele reconstrói os debates em torno da emergência do sufrágio universal na França, na história de uma dupla transiçáo: de simples consentimento ao auto-governo, por um lado, e do povo figurado como um corpo ao indivíduo autônomo, do outro. Nos momentos imediatamente posteriores à Revolução, o princípio de igualdade política não está em questão, já que todos os indivíduos têm o mesmo peso na decisão e legitimação política. 
Um homem, uma voz, um voto. A equação simples se nos impôe com a força da evidência. A igualdade diante da urna eleitoral é para nós a condição primeira da democracia, a forma mais elementar de igualdade, a base mais indiscutível do direito ${ }^{5}$ (ROSANVALLON, 1992, p. 11).

O caráter hoje incontestável do sufrágio universal, pedra angular de todo o sistema político, é, porém, segundo o autor, uma unanimidade bastante recente. Durante a primeira metade do século 19 , as elites liberais denunciavam o sufrágio universal como uma ameaça de subversão da política pelas 'paixôes do número'.

E se as mulheres só votam há meio século, isso parece uma questão longínqua em nossas mentes, extraordinariamente distante, que nos remete ao que nos parece ser um tipo de era pré-histórica da sociedade moderna, quase incompreensível (ROSANVALLON, 1992, p. 11).

As interrogaçôes sobre a oportunidade política e a validade filosófica da extensão a todos os indivíduos do direito de sufrágio estiveram, durante longos decênios, no centro da vida intelectual e dos debates políticos (1992, p. 12). O sufrágio universal é a grande questão do século 19 e "é em torno dela que se polarizaram os fantasmas sociais, as perplexidades intelectuais e os sonhos políticos". Ela amarrou todas as interrogaçóes sobre o sentido e as formas da democracia moderna: a respeito dos direitos civis e direitos políticos, da legitimidade e do poder, da liberdade e da participação, da igualdade e da capacidade.

Se a democracia é ao mesmo tempo um regime (poder do povo) e uma religião (a celebração de uma mítica sociedade dos iguais), ela encontra na ideia de sufrágio universal sua dupla matriz, o lugar de expressão de sua ambivalência, o ponto de tensão de sua significação (ROSANVALLON, 1992, p. 13).

Rosanvallon destaca a formidável ruptura intelectual que a ideia de igualdade política introduziu nas representaçôes sociais dos séculos 18 e 19. A igualdade política instaura um tipo de relaçáo inédita entre os homens, distante, segundo ele, das interpretações liberais e cristãs. A ideia de igualdade política "opera uma revolução no

\footnotetext{
5 «Un homme, une voix. L'équation simple s'impose à nous avec la force de l'évidence. L'égalité devant l'urne électorale est pour nous la condition première de la démocratie, la forme la plus élémentaire de l'égalité, la base la plus indiscutable du droit » (ROSANVALLON, 1992, p. 11).
} 
interior mesmo da nova ordem liberal que se afirma a partir do século 17" (ROSANVALLON, 1992, p. 14).

O direito de voto não é, para ele, somente uma liberdade formal. A igualdade política 'marca a entrada no mundo dos indivíduos', afirma um tipo de 'equivalência de qualidades', em ruptura com 'visóes tradicionais do corpo político'. A igualdade política só pode ser formulada no quadro de uma visão atomística e abstrata da formação dos vínculos sociais. Para Rosanvallon, a igualdade não pode ser pensada a não ser na perspectiva de um individualismo radical, contrariamente a outras formas de igualdade, que, segundo ele, podem perfeitamente se acomodar a uma organizaçáo hierárquica ou diferenciada do social.

A igualdade política definida nesses termos aproxima e anula "aquilo que há de mais naturalmente diferente entre os homens: o saber e o poder" (ROSANVALLON, 1992, p. 15). Para Rosanvallon, essa é a forma 'mais artificial e mais exemplar' de igualdade. Nem as categorias da justiça distributiva, nem as da justiça comutativa conseguem apreendê-la. O sufrágio universal é assim um tipo de sacramento de igualdade entre os homens.

Rosanvallon retém de Claude Lefort a convicção de que a teoria marxista herdada não fornecia as ferramentas necessárias para o tipo de crítica à hierarquia e defesa do pluralismo e experimentação que políticas esquerdistas parecem demandar desde 1968. Por meio de sua narrativa da modernidade, gerada pela reflexão sobre as origens profundas do totalitarismo, Lefort sugere que o totalitarismo emerge da extirpação do político como tal. Em sua tese (LEFORT, 1972), supervisionada por Raymond Aron, Lefort adota a visão de Maquiavel a respeito da inevitabilidade do conflito, para criticar a tradição marxista em sua esperança, em nome da unidade póspolítica, de transcender a divisão. Rosanvallon segue Lefort na tentativa de considerar a questão da emancipação política a partir do ponto de vista das teorias 'realistas' da dominação (Maquiavel, La Boétie, Pareto), em vez de considerá-la pelo prisma da teoria marxista, em que dominação é sobretudo dominação econômica, da qual a dominação política é simplesmente uma derivação (JAINCHILL e MOYN, 2004).

Rosanvallon, seguindo a crítica de Lefort ao pontocego da visão marxista, argumenta que a ideia de autogestão, cujo exame marcou o início de sua carreira acadêmica, demanda a "reabilitaçáo do político", e, portanto, a rejeição das cegueiras da utopia e da tecnocracia, que pretendem ambas transcender o político/a política. $\mathrm{O}$ 
desejo de reabilitar o político tem sido um tema central ao longo de sua carreira ${ }^{6}$, desde a retomada da ideia de autogestão, concebida como uma nova forma de liberalismo político, segundo ele inteiramente separada do liberalismo econômico.

Para Rosanvallon, o liberalismo político corretamente impôs limites ao Estado e respondeu à necessidade de flexibilidade pluralista, sem nunca resolver o problema de adaptaçáo às mudanças tecnológicas e industriais, e assim permaneceu congelado no século 18, sendo incapaz de ultrapassar os limites da questáo das liberdades públicas e individuais. Entáo ele atribui a si mesmo a tarefa de descobrir formas políticas bem adaptadas a uma sociedade complexa e desenvolvida.

Assim, sua teoria da autogestáo recuperaria elementos do liberalismo político de sua implicaçáo inicial com a defesa da propriedade individual e "atualizaria Locke". Mas também corrigiria o liberalismo político, assegurando que o liberalismo não se restrinja à função negativa de impedir a intervenção predatória do Estado na sociedade, sem também propiciar meios mais positivos de criar uma sociedade civil vibrante e pluralista. Segundo o autor, enquanto a ideia de autogestão herda do marxismo a crítica da sociedade burguesa e do liberalismo o princípio de reduzir o poder do Estado e de tornar a sociedade civil soberana, ela vai além de ambos (ROSANVALLON, 1976).

À consensual rejeição do totalitarismo no pensamento francês de então, Rosanvallon (1979, p. 5) acrescenta outra missão: "um trabalho imenso precisa ser feito agora na definição de alternativas positivas para manter nossa ambição de transformar a sociedade”. Pierre Rosanvallon então estende a crítica do totalitarismo ao espectro totalitário presente na história do próprio liberalismo. Em Le capitalisme utopique, o autor tenta mostrar o desejo proto-totalitário por homogeneidade monística e transparência harmoniosa que ele percebia latente nas visóes do mercado no século 18. "A utopia liberal econômica do século 18 e a utopia socialista política do século 19 parecem ser duas faces iguais e opostas da mesma representaçáo da sociedade" (ROSANVALLON, 1979, p. 5-6).

Em vez de rejeitar a crítica do totalitarismo, Rosanvallon procura estendê-la e enraizá-la profundamente nas origens do próprio liberalismo, e não apenas na democracia:

\footnotetext{
${ }^{6}$ Ver: Oliveira Jr. (2012), Lynch (2010) e Faria (2010).
} 
Todos os fundamentos intelectuais do liberalismo utópico abrem caminhos muito mais brutais. A recusa do político, a utopia de uma sociedade transparente, a crítica de estruturas sociais intermediárias autônomas: tudo está no lugar para uma sociedade totalitária (ROSANVALLON, 1979, p. 160).

Como resultado, Rosanvallon (1979, p. 229) afirma que "é talvez a modernidade mesma que agora seja necessário interrogar e botar atrás das grades". Razão e vontade, racionalismo e voluntarismo, harmonia econômica e unidade política: cada par emerge, na visão de Rosavallon, como a dupla face da mesma patologia (JAINCHILL e MOYN, 2004).

$\mathrm{Na}$ conclusão de Le capitalisme utopique, Rosanvallon rejeita a ilusão de que o governo da lei e os direitos do homem possam promover um conteúdo suficiente para o liberalismo e fala de "uma teoria política simultaneamente realista e revolucionária", como um "projeto crítico para o futuro da democracia" (ROSANVALLON, 1979, p. 230).

Rosanvallon, bem como outros intelectuais neoliberais, retoma os temas dos debates dos anos 1970: o fim do totalitarismo, a renovaçáo da democracia, a ultrapassagem da alternativa entre estatismo e privatismo. Para Jainchill e Moyn (2004), Rosanvallon colocou, mas não resolveu a questão fundamental de como imaginar a sociedade moderna comprometida com a liberdade e igualdade que poderia evitar a tentaçáo totalitária de unidade que Rosanvallon viu nas origens de ambos, liberalismo e democracia. E se dedicou então à ousada, porém difícil, empreitada de buscar, no passado, fontes de solidariedade política compatíveis com a necessidade de pluralismo social.

Pierre Rosanvallon, curiosamente, pertence ao movimento autodenominado 'segunda esquerda', mas também costuma ser associado ao 'neoliberalismo francês', que caracterizava alguns dos pesquisadores reunidos em torno de François Furet (JAINCHILL e MOYN, 2004). Inspirado na proposta de seu mestre François Furet, que revisou a história da revolução francesa no intuito de demonstrar o caráter totalitário da democracia, como se a democracia tendesse fatalmente ao terror, Rosanvallon pretende ampliar essa ideia de Furet para o liberalismo.

$\mathrm{O}$ autor escreveu duas trilogias, enquanto a primeira faz uma recuperação da história do sufrágio e da democracia representativa na França, por meio da análise dos 
debates que se deram durante o período pós-revolucionário ${ }^{7}$, a segunda trata das transformaçóes da democracia no século 21, elabora uma crítica à política eleitoral, a partir do diagnóstico de mal-estar na democracia eleitoral e crise de representação política, o autor analisa formas alternativas de ação contra-democrática e formas emergentes de legitimidade democrática, que desembocam na ideia da sociedade dos iguais.

A sua segunda trilogia parte das premissas da patologia democrática e da opacidade da representação política e opera com três categorias que se articulam na sua análise das feiçôes assumidas pela democracia contemporânea. Sáo elas: imparcialidade, reflexividade e proximidade. Essas categorias, em Rosanvallon, se articulam na definição de igualdade política e caracterizam aquilo que o autor denomina por 'sociedade dos iguais'. As duas trilogias compóem, juntas, sua visão sobre a configuração histórica das relaçóes entre democracia e liberalismo e apresentam uma continuidade na obra de Rosanvallon.

\section{Novas formas de legitimidade contra-democrática}

Em La contre-démocracie, Rosanvallon (2006) designa o conjunto de instrumentos de vigilância e avaliaçáo dos governos que concorrem ao exercício da cidadania. Esses instrumentos - o vigiar, o impedir e o julgar - exercem um contrapoder para limitar o "absolutismo dos governantes", que foram legitimados pela sagração das eleiçóes.

Práticas de vigilância contra-democrática são mais antigas que a democracia representativa - o autor se refere à China Imperial e à Esparta - e a consolidaçáo das emergentes "democracias modernas" implicou a tentativa de institucionalizá-las ${ }^{8} . \mathrm{Na}$ visão do autor, tais tentativas de institucionalização têm sido um fiasco, visto que hoje tais funçôes de vigilância são asseguradas de maneira informal - mas não menos eficazes, pelos atores e organizaçóes da sociedade civil. Visto que não foram devidamente institucionalizadas, é a sociedade civil organizada que assegura, "informalmente", as funçôes de vigilância.

A figura contra-democrática da vigilância se realiza sob três modalidades que mobilizam determinados grupos e agentes. São elas: a vigilância simples, exercida por

\footnotetext{
${ }^{7}$ A primeira trilogia compreende as obras Le sacre de citoyens (1992), Le peuple introuvable (1998) e La démocratie inachevée (2000).

8 Rosanvallon cita o "Conselho dos Censores" na Constituição da Pensilvânia, em 1776, e o "Tribunat" da Constituição do ano VIII da República (1799), atualmente (desde 1958) denominado "Conselho Constitucional".
} 
comitês de cidadãos; a denúncia, exercida, sobretudo, pela imprensa; e a notação, exercida por "especialistas".

A imprensa, segundo o autor, tem o papel de pôr à prova a reputação dos governantes. A "notação" é exercida por "especialistas", desde agências de classificação de risco a observatórios e comitês de usuários, que submetem a qualidade das decisóes e a competência dos governantes a uma apreciação "documentada e argumentada", segundo Rosanvallon.

$\mathrm{O}$ autor, porém, não problematiza o papel da imprensa enquanto um ator político interessado, nem a intensa presença de interesses econômicos que orientam a formação da agenda pública pela mídia, nem seu poder de definição do escopo da controvérsia legítima, nem os efeitos de longo prazo no cultivo das concepçóes de realidade dos cidadãos. Parece, por sua vez, ver as instituiçôes midiáticas como fontes neutras de informação?.

O poder contra-democrático do povo se manifesta, também, segundo Rosanvallon, na soberania do impedimento, que permite ao povo vetar (ou expressar seu veto a) decisóes ou açóes dos governantes. As figuras do impedimento também são múltiplas e antigas (o autor elenca exemplos táo díspares como o poder dos tribunais romanos, a doutrina medieval do direito de resistência à opressão, a greve geral e o "culto do engajamento" do rebelde, do resistente ou do dissidente). Rosanvallon, no entanto, observa um esgotamento e empobrecimento do sentido do impedimento quando é incorporado a um voto que tende cada vez mais a expressar uma rejeição dos governantes em vez de adesão a um programa político ou a uma relação de confiança entre os seres humanos.

O controle popular também se faz presente quando o poder político e as decisôes que ele toma são submetidas ao julgamento público dos cidadãos, que é, ao lado do voto, uma de suas atividades essenciais. Tais instrumentos, porém, também podem concorrer para o enfraquecimento da democracia e revelar a distância que separa governantes de governados. Face a uma sociedade mobilizada, mas dividida, os governos veem sua capacidade de agir ser fortemente limitada, enquanto se abrem caminho aos "excessos populistas", fundados sobre a promessa de uma política que respondesse às aspiraçôes de um povo ficcionalmente reunificado.

\footnotetext{
9 Vale ressaltar que essa é uma característica comum às diferentes teorias da democracia que se desenvolveram no âmbito do liberalismo político (MIGUEL, 2000).
} 
Para Rosanvallon, náo se trata de opor a essa crise da democracia representativa, uma democracia participativa, que seria esperado que exprimisse a verdadeira vontade do povo, mas sim o fato de se encontrar o caminho a uma nova relação positiva com a política, fundada sobre a adesão a um projeto que recupere o sentido de viver juntos. Em La legitimité démocratique (2008), o autor afirma: "O povo é a fonte de todo poder democrático". Mas a eleição não garante que um governo esteja a serviço do interesse geral, tampouco que ele subsista.

Isso se dá porque um poder não é doravante considerado como plenamente democrático se não for submetido ao controle de testes e validaçôes, ambos concorrentes e complementares da expressão eleitoral majoritária. Ele deve, assim, respeitar uma tripla exigência de distanciamento de posições partidárias e interesses particulares (legitimidade de imparcialidade), consideração das expressóes plurais do bem comum (legitimidade de reflexividade) e de reconhecimento de todas as singularidades (legitimidade de proximidade). Daí o autor aponta como resultados desta "revolução da legitimidade" o desenvolvimento de instituiçóes como as 'autoridades independentes' e as 'cortes constitucionais', bem como a emergência de um governo sempre atento aos indivíduos e às situaçóes particulares.

Aqui vale introduzir uma ressalva, pois discordamos do entendimento que o autor francês parece ter da ideia de democracia participativa. A teoria da democracia participativa, tanto na perspectiva elaborada por Carole Pateman (1992) quanto na proposta de C.B. Macpherson (1977), não opõe representação à participação, mas trata da instituiçáo de procedimentos democráticos em espaços sociais que propiciem a participação com voz e voto, o que poderia capacitar os cidadãos à escolha eleitoral em contextos mais amplos. Tal ideia também se encontra na obra de Robert Dahl (1990), "Um prefácio à democracia econômica", em que o autor defende a introdução de procedimentos democráticos no local de trabalho.

No último volume da segunda trilogia, o autor define os princípios que fundamentam a sociedade dos iguais - singularidade, reciprocidade e comunalidade como condiçóes de uma solidariedade mais ativa. Em sua filosofia da igualdade, tais princípios pretendem articular uma relação social que permita ir além das teorias da justiça próprias à reflexão contemporânea. $O$ autor parte do diagnóstico do crescimento exponencial da desigualdade, que ele chama de "uma verdadeira contrarrevolução": 
Os fatores econômicos e sociais que engendraram essa situação são bem conhecidos. Mas a pane da ideia de igualdade também desempenhou um papel maior ao conduzir à deslegitimação do imposto e às açóes de redistribuição, ao produzir, ao mesmo tempo, uma forma de resignação e de impotência face as desigualdades (ROSANVALLON, 2011, p. 12).

Não há nada de mais urgente, portanto, segundo o autor, do que refundar a ideia de igualdade para sair dos impasses do tempo presente. Rosanvallon explica que Rawls (2000) e Habermas (2002) fizeram muito para renovar o pensamento político, mas lamenta que suas abordagens à teoria política tenham um caráter muito normativo, ignorando a complexidade da experiência democrática atual e de sua evolução não-linear ao longo do tempo. O problema proeminente, para ele, é o salto entre a legitimação procedimental, conferida por eleiçôes, e 'confiança política substantiva', crescentemente retirada dos governantes, de todo modo corretamente votados e investidos dos cargos.

Torna-se indispensável considerar então, em primeiro lugar, o caráter problemático do regime político moderno para apreendê-lo em seu movimento - e não tentar dissipar o seu enigma por uma imposição normativa, como se uma ciência pura da linguagem ou do direito pudesse indicar aos homens a solução razoável diante da qual eles haveriam forçosamente de se conformar. (...) o interesse está em tomar como objeto a característica sempre aberta e 'sob tensão' da experiência democrática (ROSANVALLON, 2010, p. 84).

A democracia contemporânea, entendida nesses termos, é um 'caso mais rico' do que os modelos exíguos propostos por Schumpeter (1987) e seus seguidores, que a concebem como apenas um método de seleção de governantes, de mera escolha entre elites concorrentes pelo poder. Sua ideia pretende ser concebida não no espírito do minimalismo, mas de um "realismo positivamente preocupado", que naturalmente permaneceria imperfeito e seria responsável por uma perversão em particular - a patologia do populismo, em que algumas formas de contra-democracia ameaçam engolir a própria democracia (ROSANVALLON, 2006).

Mas, se esse perigo demanda vigilância, o balanço dos recentes desenvolvimentos é, de longe, menos negativo do que as convencionais expressôes de desilusão com os destinos do governo representativo. O verdadeiro "fenômeno memorável” do período não foi, para Rosanvallon, nem um declínio no engajamento 
político, nem uma elevação da onda dos mercados desregulados, mas o crescimento da sociedade civil auto-organizada, expandindo uma 'democracia indireta' em torno e além dos sistemas eleitorais. Esse ganho trouxe consigo uma perda de saliência da esfera política, concebida de forma restrita (ROSANVALLON, 2000).

Perry Anderson afirma que, apesar de a abordagem de Rosanvallon à democracia, passada e presente, ser empiricamente muito mais rica do que teorizaçóes de uma posição original ou razão comunicativa, essa vantagem é mais limitada do que parece e tem seu preço. Anderson afirma que, na 'história filosófica do político' de Rosanvallon, há mais filosofia do que história (ANDERSON, 2009, p. 205). Ele compara-o às visóes do passado na obra de Foucault, que consistem antes em parábolas para instruçáo presente do que verdadeiros estudos historiográficos, reunindo evidências que corroborem filosofemas concebidos independente delas.

Mais claramente do que nos casos de Rawls (2000) e Habermas (2002), autores a quem Rosanvallon se contrapóe, essa é uma proposta apologética. Enquanto os primeiros autores esboçam uma ordem normativa inscrita nas instituiçóes e entendimentos existentes nas sociedades ocidentais, ainda que na prática sejam frequentemente distorcidas por ambos, Rosanvallon se move para a direção oposta, buscando mostrar, na segunda parte da sua obra, que consiste numa incompreensáo da nossa democracia existente supor que ela falha em realizar os valores da soberania popular, aos quais ela preencheria de maneiras mais sutis e mais ricas do que usualmente imaginado.

A função do argumento de Rosanvallon é a de uma compensação ideológica, pois, ao invés de lamentar a queda do sistema eleitoral como veículo da vontade popular, nós deveríamos celebrar a emergência de formas não eleitorais de accountability e do bem comum. Para Anderson,

a enorme gama de substitutos arregimentados para este fim beira, às vezes, o cômico: não apenas cortes constitucionais, procissóes de rua ou comissôes de auditoria, como também bancos centrais, agências de classificação de risco e 'conversaçôes políticas', das quais nós somos solenemente informados que há 15 milhóes por dia na grã-bretanha ${ }^{10}$ (ANDERSON, 2009, p. 207).

Anderson enfatiza que o objetivo do exercício é claro, como Rosanvallon o coloca: 'uma certa dessacralização da vida eleitoral' e a 'multiplicação de autoridades

${ }^{10}$ Cf. Rosanvallon (2008, p. 327). 
funcionais' são essenciais para aquela soberania complexa em que, pela primeira vez, a 'democracia pode ser total e completamente liberal' (ROSANVALLON, 2000, p. 407-408).

Rosanvallon assume a tarefa não tanto de ataque ao velho, mas de embelezamento do novo, por meio de uma interpretação construtiva das mudanças que sobrevieram, como um trabalho em andamento na direção de um futuro ainda mais (total e completamente) liberal. "O resultado é um incapacitante quociente de eufemismo", conferindo às suas respostas um "penetrante ar de brandura que inevitavelmente limitou seu apelo". A dimensão social desse liberalismo - o sentido no qual Rosanvallon reivindica sua posição à esquerda nos compromissos republicanos - náo compensa essa desvantagem (ANDERSON, 2009).

\section{A boa sociedade e o bom governo}

Em La société des égaux, terceiro volume de sua reflexão filosófica e histórica sobre as mutaçóes contemporâneas da democracia, o autor defende uma concepção de igualdade como uma relação a ser construída, em vez de um dado da natureza. Sua reflexão, certamente, não está isenta de normatividade. Nessa obra o autor retoma o tema da emergência e crise do Estado de bem-estar para constituir as bases de seu ideal normativo da sociedade dos iguais. A primeira parte do livro explora as revoluçôes francesa e americana, em que a igualdade é afirmada como uma dimensão inerente à configuração das relaçóes sociais. Tal afirmação de igualdade é marcada pelo voluntarismo político na França e pela experiência das realidades locais nos Estados Unidos. Daí, segundo o autor, emergiria um ideal democrático como forma de sociedade que não poderia ser reduzida a um regime político, visto se tratar de uma sociedade de semelhantes, não construída sobre a base de uma mesma natureza humana, ou de identidades homogêneas, mas em razão dos liames sociais nos quais uns e outros se constituem: a um só tempo uma sociedade de individuos independentes e uma comunidade de cidadãos. Nesse sentido,

o direito de voto não é somente um atributo pessoal, ele é indissociável da existência de uma coletividade: aquela que forma o agrupamento dos cidadãos. Os dois elementos - possessão de um direito pessoal e constituição de uma comunidade - se superpóem com evidência no momento das revoluçóes americana e francesa (ROSANVALLON, 2011, p. 58). 
Seu projeto de uma 'sociedade sem barreiras' consiste em religar indivíduos que se percebem a partir de suas condiçóes diferentes, determinadas antes por sua história do que por sua condiçáo. "As desigualdades resultam doravante tanto de situações (logo individuais) que se diversificam quanto de condições (logo sociais) que se reproduzem" (ROSANVALLON, 2011, p. 309).

Tais desigualdades não têm, segundo o autor, o caráter evidentemente objetivo, "logo psicologicamente 'tranquilizador' das igualdades tradicionais de condição" (ROSANVALLON, 2011, p. 309). Nesse sentido, a ideia de igualdade deve ser reformulada, em uma era de reconhecimento das singularidades individuais.

O desafio é o de constituir uma 'economia política ampliada' do liame social que permita fundar uma verdadeira teoria geral da igualdade, integrando suas diferentes dimensóes para conferir bases sólidas e universalizáveis às açóes reformistas (ROSANVALLON, 2011, p. 354).

Nesse livro o autor se refere mais claramente ao problema das desigualdades sociais estruturais, mas o faz em termos de 'igualdade de condiçóes', e procura manter-se eqüidistante tanto do liberalismo conservador, que invoca a natureza humana para justificar as divisóes sociais, quanto do comunismo utópico, simetricamente oposto, que define a igualdade como assimilação a uma humanidade reconciliada.

\begin{abstract}
Afirmar que cada um tem uma quota equivalente de soberania, que tem a mesma capacidade de dar um parecer sobre os princípios de organização da vida em comum, vai muito mais longe do que simplesmente proclamar os direitos à liberdade de expressão, à dignidade, à segurança, à subsistência. Pode-se sustentar nesse sentido que a ideia democrática introduz na humanidade uma ruptura intelectual muito maior do que a ideia socialista. A utopia de uma sociedade economicamente igualitária foi formulada alhures muito antes da aparição da ideia de igualdade política. Em sua origem, o socialismo propôs realizar uma comunidade social de irmãos, muito mais do que uma sociedade política de iguais (ROSANVALLON, 2011, p.58).
\end{abstract}

Diante dos dilemas práticos e teóricos da mudança na gramática das reivindicaçôes políticas discutida por Nancy Fraser (1997), em que demandas por reconhecimento vêm substituindo reivindicaçóes por redistribuição e promovendo uma mudança no imaginário político, especialmente nos termos em que a justiça é 
imaginada - mudanças que caracterizam o que ela chama de condição pós-socialista ${ }^{11}$ - Rosanvallon defende candidamente que as desigualdades materiais podem encontrar uma forma de correção na qualidade de um laço social mais neutro e cotidiano: aquele da simples civilidade. Ele também se vale da ideia de fraternidade situando-a no quadro de uma 'economia geral da igualdade', em que a evocaçáo de laços de família entre os cidadãos os leva a uma reeducação do olhar que têm uns dos outros, e os incita a considerarem-se como semelhantes, abstraindo tudo aquilo que pode os distanciar, dividir ou diferenciar (ROSANVALLON, 2011).

No horizonte de expectativas descortinado pelo autor nessa obra se vislumbra aquilo que ele chama de democracia integral, que seria o resultado da interpenetração dos ideais do socialismo e da democracia: "O futuro da ideia socialista no século 21 será decidido em torno do aprofundamento do ideal democrático" (ROSANVALLON, 2011, p. 23).

Em sua obra mais recente, Le Bon Gouvernement (2015), o autor retoma a questão da crise de representação e do não cumprimento dos ideais democráticos, não obstante a existência de eleiçôes e de direitos e garantias individuais, para delinear sua concepção ideal de governo democrático, enfatizando a relação entre governantes e governados, uma vez que o regime democrático consagrado nas urnas não garante que sejamos governados democraticamente.

O autor analisa a tendência à presidencialização das democracias eleitorais, que subordinam o poder legislativo, como a principal causa de desencantamento dos cidadãos em relação à política. Para reduzir a distancia separa eleitos de eleitores ele reivindica maior transparência das açôes governamentais, tornando-as compreensíveis e avaliáveis - tarefa que ele atribui às ONGs, à mídia e às redes sociais - com base no que ele chama de o 'direito de saber', para acabar com as suspeitas a que se prestam as instituiçóes públicas. Sua crítica se volta nessa obra aos tecnocratas, carreiristas e homens e mulheres da máquina política que constituem hoje os batalhôes mais fornidos da classe política, lamentando a ausência de políticos com vocação, no sentido weberiano (ROSANVALLON, 2015, p. 389).

O restabelecimento de relaçôes democráticas entre governantes e governados requer o restabelecimento de uma relação de confiança, hoje fortemente degradada.

\footnotetext{
11 "An absence of any credible overarching emancipatory projecto despite the proliferation of fronts of strugle; a general decoupling of the cultural poltics of recognition from the social politics of redistribution; and a descentering of claims of equality in the face of agressive marketization and sharply rising material inequality"(FRASER, 1997, p. 3).
} 
Rosanvallon retoma o modelo antigo do representante como fiduciário (ROSANVALLON, 2015, presente nos debates sobre mandato livre e mandato imperativo ${ }^{12}$, para realizar aquilo que ele chama de democracia de exercício, além da já referida necessidade de instituiçóes que assegurem tais tarefas, deslocando a confiança da relação de representação para as tais 'autoridades funcionais' - que nessa obra aparecem como 'organizaçóes de vigilância cidadã' (ROSANVALLON, 2015) - ele aponta a integridade e a veracidade como qualidades essenciais do bom governante, necessárias para reconstruir a relação cognitiva constitutiva da confiança.

\section{Impolitico e populismo: os perigos da legitimidade contra- democrática}

O ponto positivo da formulação do autor é romper com a ideia de que o voto é o único meio de participação política legítima. Ao pôr em questão a visão estreita que mede o grau de democratizaçáo de uma sociedade apenas por meio de critérios da democracia representativa, ele defende que a vida democrática é definida por outras ordens de legitimidade. Rosanvallon, porém, evita cair em uma glorificação de todas as práticas contestatórias que emergem da sociedade civil, pois a hipertrofia da necessária desconfiança contra-democrática é também fonte de um problema político contemporâneo maior: não a passividade do cidadáo, mas o "impolítico".

Com o conceito de impolítico, o autor propóe designar a incapacidade de apreensão global dos problemas ligados à organização do mundo comum, que tem como efeitos a dissoluçáo das expressôes de pertencimento e o mascaramento da legibilidade da ordem social. Para ele, "não há mais o político se as ações políticas não podem mais ser inscritas em uma mesma narração e representadas sobre uma cena pública única” (ROSANVALLON, 2006, p. 29).

Práticas reativas e reivindicaçôes individualistas podem culminar na expressão mais radical do impolítico, que o autor denomina como "populismo". O uso desse conceito requer maior explicitação, visto que se trata quase sempre de um termo de acusação, assim como o conceito de massa é frequentemente utilizado para deslegitimar os movimentos políticos das classes populares ou grupos políticos identificados com causas populares. Mas o autor se vale dessa noção com o sentido de "patologia social", induzida pela "vampirização total da atividade política pela contrademocracia” (ROSANVALLON, 2006, p. 29), em que a vigilância se converte em estigmatização compulsiva e permanente de autoridades governantes, em que o

\footnotetext{
${ }^{12}$ Sobre esse ponto ver, principalmente, Pitkin (1967) e Manin (1997).
} 
impedimento e a deposição dos governantes se convertem no único fim da ação política, e a função de acusação absorve toda a atividade cívica.

Frente às aspiraçôes emancipatórias presentes no ideal democrático, a proposta de Rosanvallon, entretanto, cumpre um papel legitimador do liberalismo. Ao desqualificar a representação política formal, ele se posiciona ao lado da perspectiva contemporânea de criminalização da política eleitoral, único espaço de abertura do sistema político, que se submete periodicamente à autorizaçáo popular.

As constantes tentativas de diminuir a participação popular nas decisóes políticas comprovam o propósito elitista de transformar o direito de sufrágio em um meio de os ricos comprarem poder político. A desqualificação da política eleitoral, no entanto, deslegitima a única instância em que o povo tem alguma possibilidade de intervir no sistema político e, nesse sentido, também possui um caráter despolitizador, ao fomentar o desprezo à representação política, em benefício de poderes não eleitos, e ao eliminar a política em benefício da economia. Ou seja, se os cidadáos não se sentem representados pelos políticos eleitos, deixemos aos detentores de poder (econômico) não eleitos a condução das questóes públicas.

A despeito de seu impulso democrático inicial - e de sua alegada posição à esquerda da chamada "nova teoria francesa" 13 -, embora o autor aponte a despolitização como um dos riscos da "democracia impolítica", sua proposta também despolitiza a democracia ao naturalizar as desigualdades estruturais e não problematizar a predominância de imperativos econômicos no processo eleitoral e também nas estratégias de desestabilização e de criminalização da atividade política levadas a cabo pelas autoridades funcionais.

Luanda Dias Schramm é Doutora em Ciência Politica, pela Universidade de Brasília. É Professora Substituta da Escola de Comunicação da Universidade Federal do Rio de Janeiro. E-mail: luandaschramm@msn.com.

\footnotetext{
${ }^{13}$ Tal como apresentou-se ao ambiente acadêmico estadunidense "new french theory", com o intuito de distinguir-se da constelação "french theory", título que abrigava, no imaginário anglófono americano, autores como Foucault, Deleuze, Derrida, Lévi-Strauss, Sartre, Bourdieu, entre outros.
} 


\section{Referências}

ANDERSON, Perry. The New Old World. London: Verso Books, 2009.

DAHL, Robert A. Um prefácio à democracia econômica. Rio de Janeiro: Jorge Zahar, 1990.

DUMONT, Louis. $O$ individualismo: uma perspectiva antropológica da ideologia moderna. Rio de janeiro: Rocco, 1993.

FARIA, Alessandra M.T. Do social e do político: teorias da representação política. Paper apresentado ao $34^{\circ}$ Encontro Anual da ANPOCS, 2010.

FRASER, Nancy. Justice interrupts - critical reflections on the 'post-socialist' condition. Routledge: New York \& London, 1997.

HAYEK, Friedrich A. Os Fundamentos da Liberdade. São Paulo: Visão, 1983 [1960].

HABERMAS, Jürgen. Três modelos normativos de democracia. In: A inclusão do outro: estudos de teoria política. São Paulo: Ediçóes Loyola, p. 277-292, 2002.

HELD, David. Models of democracy. Stanford University Press, 1996.

HIRSCHMAN, Albert O. De consumidor a cidadão: atividade privada e participação na vida pública. São Paulo: Brasiliense, 1983.

JAINCHILL, Andrew; MOYN, Samuel. French Democracy between Totalitarianism and Solidarity: Pierre Rosanvallon and Revisionist Historiography. The Journal of Modern History 76, University of Chicago, p. 107-154, 2004.

LEFORT, Claude. A invenção democrática: os limites da dominação totalitária. São Paulo: Brasiliense, 1972.

LOSURDO, Domenico. Democracia ou bonapartismo: o triunfo e decadência do sufrágio universal. Rio de Janeiro: Editora UFRJ, São Paulo: Editora UNESP, 2004.

LYNCH, Christian Edward Cyril. A democracia como problema: Pierre Rosanvallon e a escola francesa do político. In: ROSANVALLON, Pierre. Por uma história do político. São Paulo: Alameda, p. 9-36, 2010.

MACPHERSON, Crawford Brough. A democracia liberal: origens e evolução. Rio de Janeiro: Zahar editores, 1977.

MANIN, Bernard. The principles of representative government. Cambridge University Press, 1997.

MIGUEL, Luis Felipe. A democracia domesticada: bases antidemocráticas do pensamento democrático contemporâneo. DADOS - Revista de Ciências Sociais, Rio de Janeiro, v. 45, n. 3, p. 438-511, 2002.

Um ponto cego nas teorias da democracia: os meios de comunicação. $B I B$, Rio de Janeiro, n. 49, p. 51-77, $1^{\circ}$ semestre de 2000.

OLIVEIRA JR, Carlos Mauro de. História política e História dos Conceitos: um estudo sobre 'o político’ na obra de Pierre Rosanvallon e Marcel Gauchet. Revista História da Historiografia, Ouro Preto, número 9, agosto, 2012, pp. 166-183.

PATEMAN, Carole. Participação e teoria democrática. Rio de janeiro: Paz e terra, 1992.

PITKIN, Hanna. The concept of Representation. University of California Press, 1967.

RAWLS, John. Uma Teoria da Justiça. São Paulo: Martins Fontes, 2000.

ROSANVALLON, Pierre. Le Bon Gouvernement. Paris: Éditions du Seuil, 2015

La société des égaux. Paris: Éditions du Seuil, 2011.

Por uma história do político. São Paulo: Alameda, 2010.

La Legitimité démocratique: impartialité, réflexivité, proximité. Paris: Éditions du Seuil, 2008. 
. La contre-démocratie: la politique à l'âge de la défiance. Paris: Éditions du Seuil, 2006.

. La démocratie inachevée: histoire de la souveraineté du peuple en France. Paris: Gallimard, 2000. 1998.

. Le peuple introuvable: histoire de la représentation politique en France. Paris: Gallimard,

. Le sacre du citoyen: histoire du suffrage universel en France. Paris: Gallimard, 1992.

. La Autogestión. Madrid: Editorial Fundamentos, 1979.

. L'âge de l'autogestion. Paris: Éditions du Seuil, 1976.

SCHUMPETER, Joseph A. Capitalismo, socialismo e democracia. Rio de Janeiro: Jorge Zahar Editores, 1987.

URBINATI, Nadia. O que torna a representação democrática? Lua Nova, São Paulo, n. 67, 2006, p. 191-228.

Texto recebido em 25 de outubro de 2016.

Aprovado em 06 de dezembro de 2016. 